\title{
TEMPORAL VARIABILITY OF CHLOROPHYLL-A IN THE SÃO VICENTE ESTUARY
}

\author{
André Francisco Bucci, ${ }^{1, *}$, Áurea Maria Ciotti ${ }^{l}$, Ricardo Cesar Gonçalves Pollery ${ }^{2}$, Renan de Carvalho ${ }^{l}$, \\ Heitor Cavalcanti de Albuquerque ${ }^{l}$ and Leonardo Tomida Spalletti Simões ${ }^{2}$
}

${ }^{1}$ Centro de Biologia Marinha - Universidade de São Paulo (CEBIMar/USP) (Rodovia Manoel Hypólito do Rego, Km 131,5, s/n, 11600-000 São Sebastião, SP, Brasil)

${ }^{2}$ Universidade Federal do Estado do Rio de Janeiro

Laboratório de Biogeoquímica Departamento de Ecologia Instituto de Biologia

(Rua Brigadeiro Trompowski, s/n, 21941-590, Rio de Janeiro, RJ, Brazil)

*Corresponding author: bucci.andre@gmail.br

\section{A B S T R A C T}

Estuaries are extremely dynamic environments that are vulnerable to anthropogenic alterations. Thus, monitoring phytoplankton abundances and composition is an essential tool for the prediction of eutrophication and its effects on coastal ecosystems. Phytoplankton biomass, as chlorophyll-a, in the São Vicente estuary (Brazil) varies in response to tidal cycles and seasonal rainfall. Objectives. To present two datasets designed to assess the relationship between chlorophyll-a and changes in water turbidity driven by tide and rain. Methods. Weekly observations were made in the shallow embayment (February to September 2008; site 1) and observations recorded on alternate days (summer 2010, site 2). Results. At site 1, turbidity differed between high and low tides, but on most days was over $3000 \mathrm{RU}$, maintaining moderate chlorophyll-a levels $\left(4 \mathrm{mg} . \mathrm{m}^{-3}\right)$ and only two blooms developed during low turbidity. Site 2 mean turbidity was 1500 RU, nutrient level was higher during neap tides and phytoplankton blooms were mainly observed at the end of neap tides at 15-day intervals, dominated by chain-forming diatoms and occasionally flagellates and pennate diatoms. Conclusions. Taxonomic composition of the blooms was different and their frequency altered by events characterized by intense freshwater discharges from the Henry Borden Hydroelectric Dam (> $9 * 106 . \mathrm{m}^{3}$ ), inhibiting phytoplankton accumulation during neap tide periods.

\section{RESUMO}

Estuários são ambientes dinâmicos e susceptíveis a alterações antropogênicas. Nesses ambientes, torna-se imprescindível monitoramento do fitoplâncton na previsão da eutrofização e de seus efeitos para o ecossistema. No estuário de São Vicente (Brasil) a biomassa fitoplanctônica, como clorofila-a, varia sazonalmente em resposta às chuvas e marés. O presente estudo visa apresentar dois programas de monitoramento para detectar florações fitoplanctônicas em relação a turbidez da água guiada pelas marés e chuvas. Métodos. As observações foram semanais na porção rasa (Fevereiro a Setembro de 2008; área 1) e observações em dias alternados no canal (verão de 2010; área 2). Os resultados mostram que a área 1, turbidez acima de $3000 \mathrm{RU}$ manteve níveis de clorofila-a médios $\left(4 \mathrm{mg} . \mathrm{m}^{-3}\right)$ e duas florações ocorreram apenas em baixa turbidez, sendo esta diferente entre marés alta e baixa. $\mathrm{Na}$ área 2, a turbidez manteve-se entre $1500 \mathrm{RU}$, os nutrientes foram maiores durante as marés de quadratura, e as florações tiveram frequência de aproximadamente 15 dias, no final da quadratura, predominando diatomáceas em cadeia e eventualmente flagelados e diatomáceas penadas. A composição taxonômica variou entre florações e o padrão quinzenal foi significativamente alterado durante eventos com alta descarga de água doce oriundos da usina hidroelétrica Henry Borden (> $9 * 106 . \mathrm{m}^{3}$ ) o que impediu o acúmulo de fitoplâncton no período das quadraturas.

Descriptors: Temporal pattern, Freshwater runoff, Phytoplankton biomass, Tide regulated estuaries. Descritores: Padrões temporais, Descarga de água doce, Biomassa fitoplanctônica, Estuários controlados por maré. 


\section{INTRODUCTION}

Estuaries are highly variable environments where nutrient concentrations are usually high and phytoplankton growth and accumulation can be limited by the availability of light (CLOERN, 1987) and controlled by estuarine flushing times (HAAS et al., 1981). Thus variables describing water quality in estuaries show a high degree of temporal fluctuation and the intermittent salinity gradients drive spatial variability of physical variables and organisms (ALPINE; CLOERN, 1992). Among the several variables used to describe the quality of water, the concentration of chlorophyll-a ([Chl], mg. $\mathrm{m}^{-3}$ ), proxy for phytoplankton biomass, rapidly reveals the relative importance, for a given area, of the disturbance or nutrient enrichment (CLOERN; JASSBY, 2010) affecting the first trophic levels and consequently the whole ecosystem.

Under natural conditions, the standing crops of phytoplankton in estuaries are greater than those in the ocean due to the continuous input of nutrients from continents. However, the presence of suspended materials in the continental runoff can also decrease light availability (CLOERN, 1987). In most shallow estuaries, vertical mixing driven by tidal currents are the main cause of changes in turbidity, thus temporal patterns can emerge from variations between ebb and flood phases as well as between neap and spring extremes. Changes in continental runoff also affect estuarine turbidity depending on its particle load and result from the precipitation rates over the estuarine system. In large estuarine systems, freshwater inflow can favor phytoplankton growth through the resulting input of nutrients (PAERL et al., 2009) or by promoting a vertical salinity stratification that retains phytoplankton in a nutrient-rich and well illuminated zone (CLOERN, 1991). Nonetheless, intense freshwater runoff episodes in small estuarine systems may flush out the local phytoplankton community (DE MADARIAGA et. al., 1992; RENDELL et. al.,1997). Differential mixing alters the community structure and the temporal predominance of species in estuaries (LAURIA et. al., 1999). While non-motile organisms, such as diatoms, benefit from the vertical mixing which keeps them within the photic zone. They lack the response mechanisms to allow them to avoid the removal beyond a critical depth due to strong vertical mixing. Motile dinoflagellate and flagellate species, however, can return to the photic zone in response to strong turbulence and even maintain their populations in the surface layers during periods of relative vertical stratification.

Estuaries are among the coastal environments most affected by human occupation, and several examples of alterations in biological community and water quality may be quoted. Port activities within estuaries lead to frequent channel dredging that may affect water transparency and the interactions between benthic and pelagic communities. Reduction in estuarine primary production has been linked to the increase in water turbidity promoted by dredging (EWA-OBOHO et al., 2008) and differential sediment transport (CHEN et al., 2005). Resuspension of bottom sediments can also bring phytoplankton resting stages to the water column as vegetative cells (SHIKATA et al., 2008), leading to the development of blooms that may include red tide species (ANDERSON et al., 1983). Input of nutrient loads (CONLEY, 2000; DE JONGE et. al., 2002) may produce changes in the periodicity and magnitude of phytoplankton blooms or even push an environment into eutrophication. Agriculture residuals (NIXON, 1995) and sewage input in coastal environments (CARPENTER et al., 1998) are the main anthropogenic cause of water enrichment and the increase of phytoplankton biomass. The control of the freshwater flow (PETERSEN et al., 2008; DYNESIUS; NILSSON, 1994) and river damming (NIXON, 2003) often disrupt the spatial distribution, temporal patterns and community structure of phytoplankton by leading to changes in river-coast chemistry (HUMBORG et al., 2000). Thus, estuaries where human occupation is intense will benefit from monitoring programs that include the observation of phytoplankton dynamics.

The Santos estuarine complex is located in a subtropical region on the southeastern Brazilian coast $\left(23^{\circ} 53^{\prime}-24^{\circ} 02^{\prime} \mathrm{S}, 4^{\circ} 27^{\prime}-46^{\circ} 15^{\prime} \mathrm{W}\right)$ (Fig. 01). The system contains one main tributary (Cubatão river) and three estuarine channels (Santos, Bertioga and São Vicente) and a coastal bay (Santos Bay). The local climate is humid with precipitation rates varying from about 150 to more than $305 \mathrm{~mm}$ per month (CBH-BS 2007), more intense during the summer months. The system also receives small daily fresh water discharges from the Billings Reservoir (city of São Paulo) through the Henry-Borden Hydroelectric Dam (city of Cubatão). During rainfall peaks in São Paulo, most frequent during the summer, posing an imminent risk of flooding, the fresh water input from the Billings Reservoir can be substantial, as underground emergency pipes drain the excess water directly into the Cubatão river. To the best of our knowledge, the impact of these episodic discharges on the phytoplankton dynamics in the Santos estuarine complex have not so far been assessed, but it is reasonable to assume that these eventual discharges increase the duration and the intensity of the flushing phases of both the São Vicente and Santos estuarine channels and disrupt nutrient and light availability.

The Santos estuarine complex is subject to increasing volumes of domestic sewage effluent and the Santos estuarine channel is dredged continuously 
(SCHMIEGELOW et al., 2008). Early studies report summer and winter phytoplankton blooms dominated, respectively, by Skeletonema cf. costatum and Asterionellopsis glacialis (MOSER et al., 2012; VILLAC et al., 2008). Moser et al. (2012) reviewed the dynamics of the phytoplankton in Santos bay and concluded that changes in microphytoplankton communities occur mainly in response to episodic changes in wind speed and direction and tides, but the results presented also give evidence of alterations in the temporal patterns of [Chl] and phytoplankton species composition during recent blooms. Despite the economic and ecological importance of the Santos estuarine complex, there is little systematic observation on phytoplankton dynamics available to date. In this study we present an analysis of two different time series of [Chl] in São Vicente estuary. Our first purpose is to characterize oscillations in phytoplankton biomass as a function of water turbidity caused by continental runoff and tides on monthly time-scales. Secondly, we identify the occurrence, during summer months, of phytoplankton blooms and characterize the disturbances in observed patterns due to local precipitation and tide regime as well as to the external inflow of fresh water.

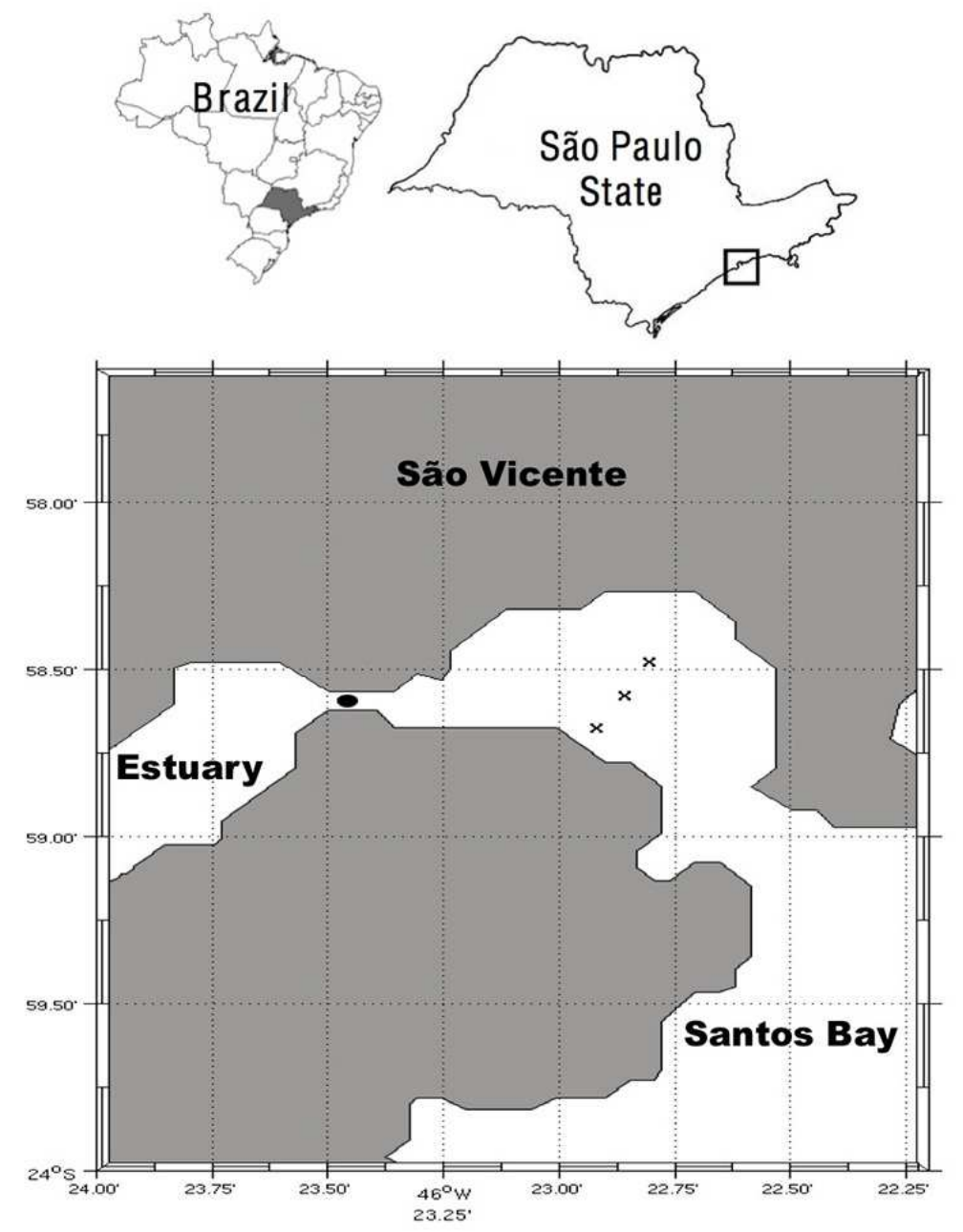

Fig. 1. Detail of the São Vicente estuarine channel located in the Santos Estuarine System. Site 1 stations $(\mathbf{X})$ were disposed in a perpendicular section at the wider region of São Vicente embayment, representing a gradient of local depth and degrees of wave exposures. Site 2 station $(\bullet)$ represents the deep channel $(10 \mathrm{~m})$ upstream of site 1. 


\section{Material ANd Methods}

Study Area

The São Vicente estuarine channel is significantly smaller than the Santos estuarine channel and connects to Santos bay through a shallow embayment (on average $4 \mathrm{~m}$ deep) subject to wave action. Two rivers (Piaçabu and Boturoca) also contribute to the freshwater discharge into the São Vicente estuarine channel. Intensive freshwater discharge due to heavy rainy contributes to the transport of material in (into?) this channel (MOSER et al., 2005). Tides are semi-diurnal with magnitudes ranging from 0.5 to $1.5 \mathrm{~m}$. The deepest portion of São Vicente channel is a narrow passage around $10 \mathrm{~m}$ deep. Numerical modeling of the main tidal components indicates asymmetries in the circulation in the São Vicente estuarine channel (HARARI; CAMARGO, 1998), common to this type of estuarine system (HARARI et al., 2000). The present study was based on two different time series performed at distinct locations in the São Vicente estuarine channel (Fig. 1) representing, respectively, the embayment (Site 1) and the deep channel further upstream (site 2). We focused on surface samples only as our main questions are related to temporal changes in phytoplankton abundance on scales from days to months. During both observation periods, daily tide amplitudes and meteorological data were downloaded from the Brazilian Navy Center of Hydrography site at http://www.mar.mil.br/dhn/chm/tabuas/index.htm and from the Brazilian National Institute of Meteorology (INMET) at http://www.inmet.gov.br, respectively. The staff of the Henry-Borden Hydroelectric Dam (EMAE - "Empresa Metropolitana de Águas e Energia S.A.", personal communication) kindly provided us with data on the daily total freshwater discharges from the Billings Reservoir $\left(\mathrm{m}^{3} \cdot \mathrm{day}^{-1}\right)$.

\section{Sampling Design}

Site 1 was visited weekly from February $20^{\text {th }}$ to September $3^{\text {rd }}, 2008$ for 28 weeks. Samples were taken twice a day, at times corresponding to the slack of low and high tides so the maximum and minimum influence of Santos bay waters could be compared. Three sampling stations were located on a perpendicular section in the widest region of the São Vicente embayment, to represent a gradient of local depth and degrees of wave exposure (TOMIDA et al., unpublished data). At each station, local water height was measured and surface water was collected and stored in a clean $5 \mathrm{~L}$ thermos flask. Samples were immediately (within 30 minutes) taken to the laboratory (at UNESP-CLP ${ }^{[1]}$ ) and salinity and temperature measured with a Handheld Conductivity Instrument (YSI 30). All the variables presented for site 1 are the averages and standard deviations for the three sampling points. Aliquot samples were used to quantify turbidity (relative units), using a Turner Trilogy fluorometer. Chlorophyll-a concentrations $\left(\mathrm{mg} . \mathrm{m}^{-3}\right)$ were measured by concentrating $250 \mathrm{~mL}$ onto $25 \mathrm{~mm}$ Whatman $\mathrm{GF} / \mathrm{F}$ filters that were immediately transferred to hermetic vials containing a pre-cooled $\left(-18^{\circ} \mathrm{C}\right)$ solution of $90 \%$ acetone:DMSO (6:4 in volume, SHOAF; LIUM, 1976) and extracted during 24 hours in the dark. The extracts were measured with a calibrated (Anacystis nidulans chlorophyll-a Sigma-Andrich standard) Turner Trilogy fluorometer, following Welschmeyer (1994). GF/F filtrates were used to quantify the light absorption coefficient of Colored Dissolved Organic Matter (CDOM), using a spectroradiometer Ocean Optics Miniature Fiber Optic Spectrometer and a $10 \mathrm{~cm}$ quartz cuvette (see BRICAUD et al., 1981). Absorption values were obtained in scanning mode from 350 to $800 \mathrm{~nm}$, but were parameterized from 350 to $600 \mathrm{~nm}$, after Babin et al. (2003), according to:

$\mathrm{a}_{\mathrm{CDOM}}(\lambda)=\mathrm{a}_{\mathrm{CDOM}}\left(\lambda_{\text {ref }}\right) * \mathrm{e}^{(-\operatorname{SCDOM}(\lambda-\lambda \mathrm{ref}))}$

to yield a magnitude $\left(\mathrm{a}_{\mathrm{CDOM}}\right)$ and the exponential decay with wavelength $\left(\mathrm{S}_{\mathrm{CDOM}}\right)$ at a specific wavelength $(\lambda)$ according to a reference wavelength $\left(\lambda_{\text {ref }}\right)$. Both parameters are used to characterize CDOM and provide insights as to the importance and origin of the organic dissolved material at a given place and time (FOSTER; MORRIS, 1974).

At site 2, near surface water samples were taken throughout the summer of 2010 (Dec $23^{\text {rd }}, 2009$ to Mar $23^{\text {rd }}, 2010$ ) on alternate days during the slack high tide. Samples were collected four times and combined two by two, resulting in 2 replicas for each sampling day, from which 6 sub-replicas were used to produce the average values used in the analysis. Phytoplankton abundance was monitored by natural fluorescence (see below) and when data suggested the formation of a possible phytoplankton bloom (increase in chlorophyll-a fluorescence), sampling became daily for the duration of the bloom. In situ water temperature and salinity were measured with a Handheld Conductivity Instrument (YSI 30). Total Chlorophyll-a fluorescence (Fchl), <20 $\mu \mathrm{m}$ fraction Chlorophyll-a fluorescence $($ Fchl $<20 \mu \mathrm{m})$ and Colored Dissolved Organic Matter (CDOM) fluorescence (relative units) of samples were measured using a Trilogy and 10-AU fluorometers (Turner Designs) after 30min of dark acclimation. Concentration of

[1]UNESP/CLP - Universidade de São Paulo, Campus de São Vicente, Praça Infante Dom Henrique s $/ \mathrm{n}^{\circ}$, Parque Bitaru 11330-900 São Vicente, SP, Brasil. 
inorganic nutrients (Ammonium, Phosphate, Nitrate, Nitrite and Silicate) was determined in a spectrophotometer (FEMTO 600plus) (Ammonium following Koroleff (1969) and Grasshoff et al. (1983); Nitrate, Nitrite, Silicate and Phosphate following Strickland and Parsons (1972)).

During bloom events at site 2, phytoplankton enumeration and identification were undertaken preserving $250 \mathrm{ml}$ of water with Formaldehyde $(\mathrm{pH}$ stabilized at 8.0 with Sodium Tetraborate), resulting in a $1 \%$ final solution. Cell counts were made with an inverted light microscope (Olympus CKX41) following Utermöhl (1931). Water turbidity and chlorophyll-a concentration determinations followed the methodology described for site 1. Tidal regime was divided into three categories according to the tidal amplitude, where Spring Tides corresponds to the days of full and new moon and 2 days before and afterwards, Neap Tides corresponds to days of first and last quarter moon and 2 days before and afterwards, Intermediary Tides corresponds to the transitional days (waning and waxing moon).

\section{Statistical Analysis}

Data analysis and temporal series treatment were conducted under the $\mathrm{R}$ environment ( $\mathrm{R}$ Development Core Team, 2011) and accessory packages, adopting statistical significance levels of $95 \%$ confidence interval and $a=0.05$. One and Twoway ANOVA were used to assess differences in variables sets. To identify predominant frequency of phytoplankton bloom occurrence in summer months (site 2) we conducted wavelet analysis using online material from the Department of Atmospheric and Oceanic Sciences, University of Colorado Boulder (http://atoc.colorado.edu/research/wavelets/). The parameters for the wavelet analysis were as follows: Morlet 6.0 mother wavelet, Powers-of-two $=11$, start scale $=1$, scale width $=0.05$, Red Noise background spectrum at $5 \%$ significance level.

\section{RESULTS AND Discussion}

Site 1 - Monthly observations

In turbid estuaries, light availability can limit phytoplankton growth (DEMERS et al., 1986) so that when turbidity decreases, conditions for the development of phytoplankton blooms improve. This is observed during the weekly time series performed at site 1 , with two events registering [Chl] above 35.00 $\mathrm{mg} \cdot \mathrm{m}^{-3}$ (Fig. 2A). Although the events occurred in March (summer) and August (winter), they both followed low water turbidity values during the slack high tide (Fig. 2B). Low tide samples were not available during the first bloom due to sampling problems, but the relative increase in chlorophyll-a concentrations prior to that day suggests that the bloom development holds good for the low tide period as well. Turbidity correlated with tides (i.e., turbid waters during spring tides and at high tides) more closely than with the local precipitation rates (Fig. 2B). Moser et al. (2012), reviewing phytoplankton dynamics in Santos bay, suggested that the estuarine complex has nutrient replete conditions all year round, with the development of Thalassiosira sp. and Skeletonema cf. costatum blooms during the neap tides in the summer, when available radiance is usually higher due to the decrease in vertical mixing. Although Thalassiosira sp. and Skeletonema cf. costatum, as other chain-forming diatoms, usually increase in abundance during summer neap tides, they are commonly found in this estuarine system (see a list of studies in the review of Villac et al. (2008)) and can be considered as estuarine or local mixers (MOSER et al., 2012). Nonetheless, qualitative microscopic data from the second bloom revealed high densities of Thalassiosira sp chains and dinoflagellates such as Alexandrium sp. The second bloom occurred after a period of weeks with no local precipitation, thus it might also indicate phytoplankton accumulation during low flushing periods.

During fall and winter months, [Chl] oscillated between 3 and $6 \mathrm{mg} \cdot \mathrm{m}^{-3}$ (Fig. 2A) and during this time, water turbidity reached values of up to 8050 [RU], values always being greater during high tides, similarly to what was found for the entire data set (Table 1). The high turbidity is probably a consequence of a more intense vertical mixing resulting from the higher winter wind speeds (HARARI; GORDON, 2001). Indeed, the São Vicente embayment may receive considerable contributions of suspended material from Santos Bay waters during spring high tides (FERREIRA et al., unpublish. data), which is confirmed by our data showing the positive relationship of salinity and suspended material $\left(\mathrm{R}^{2}=0.16, \mathrm{p}<0.01\right.$, in Table 1). Overall, the relationship between [Chl] and water turbidity is very weak, though significant $\left(\mathrm{R}^{2}=0.03, \mathrm{p}=0.04\right)$, and shows that phytoplankton biomass accumulation is never substantial when turbidity values are above 3000 [RU] (Fig. 3).

Freshwater discharges deriving from the Henry Borden Hydroelectric Dam were small throughout the site 1 sampling period, except for two isolated peaks (Fig. 2C), but the magnitude of the discharges had no significant effect on surface salinity (Table 1). Indeed, local salinity correlated with local precipitation rates during the low tides (Table 1). Daily salinity amplitudes were larger from February to mid-May (Fig. 2C), a period with higher precipitation rates, increasing the daily range of observed salinity (referred to here as delta salinity) between high and low tides $\left(\mathrm{R}^{2}=0.27\right.$, $\mathrm{p}<0.01$, in Table 1$)$. 


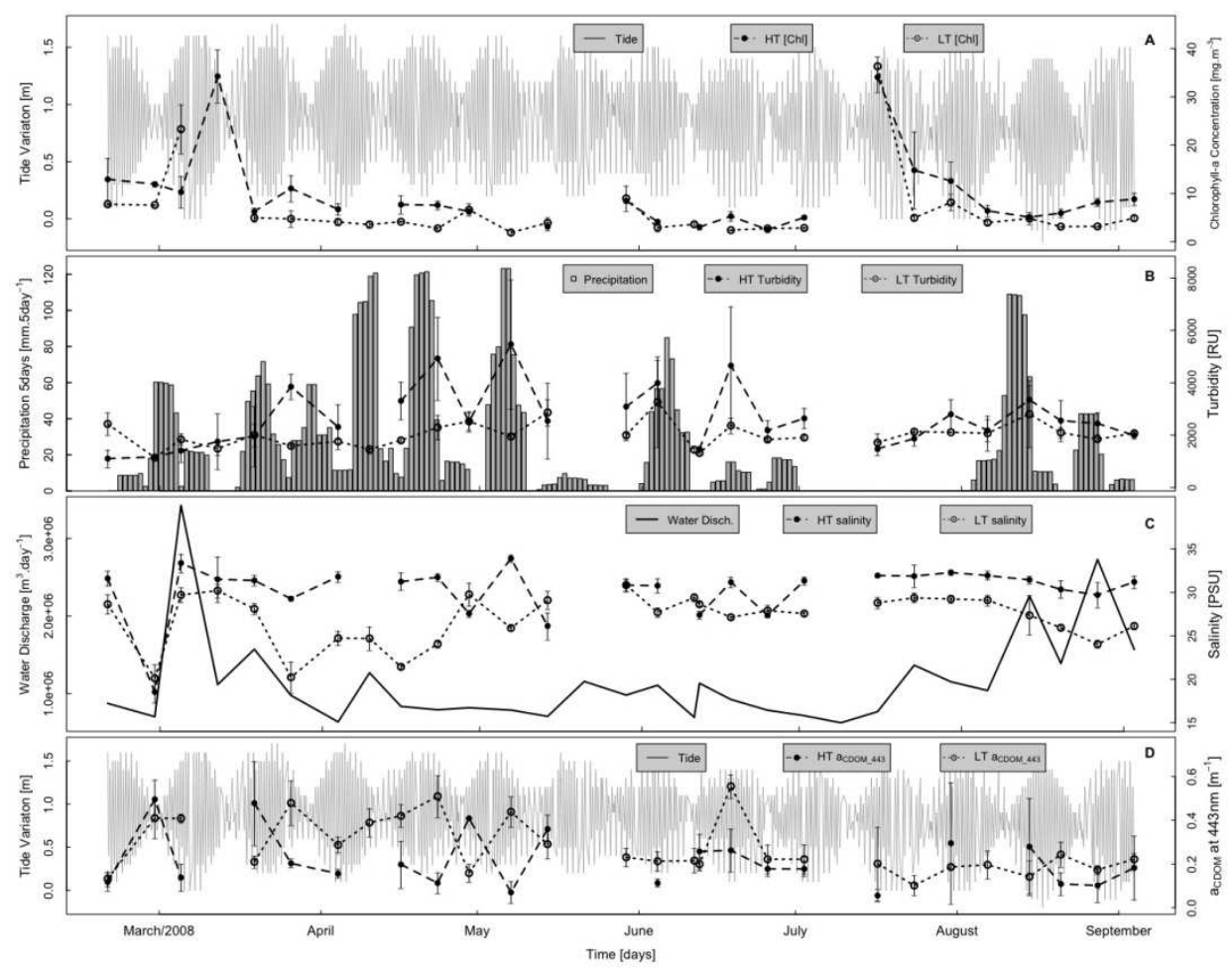

Fig. 2. Time series from site 1, where HT corresponds to "High Tide" samples and LT corresponds to "Low Tide" samples. Points represent the average of the three sampling points in site 1 and vertical bars are the standard deviation. A) Tidal variation [m] and Chlorophyll-a concentration [mg. $\left.\mathrm{m}^{-3}\right]$ divided between HT and LT; B) Precipitation rate cumulative of 5 subsequent days $\left[\mathrm{mm}_{\text {.day }}{ }^{-1}\right]$ and total water turbidity for HT and LT samples, C) Daily water discharge from Henry Borden Hydroelectric Dam $\left[\mathrm{m}^{3} . \mathrm{day}^{-1}\right]$ and salinity [PSU]

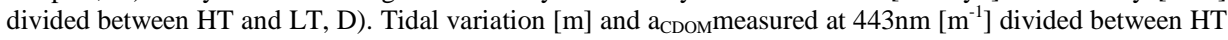
and LT. Missing data at 05/21/2008 and 07/09/2008 correspond to days of sea conditions that turned water sampling impossible. Other missing data is consequence of problems during sample processing.

Table 1. Summarization of correlations $\left(\mathrm{R}^{2}\right)$ expected from site 1 . We used three main explanatory variables (salinity, precipitation and water discharge) to explain variations in water parameters. Data was divides in High and Low Tide phases for each correlation and the overall data was also analyzed (i.e. without tide division). $\mathbf{p}$ values in bold represent statistical significance.

\begin{tabular}{|c|c|c|c|c|c|c|}
\hline & \multicolumn{4}{|c|}{ Tide Regime } & \multirow{2}{*}{\multicolumn{2}{|c|}{ Database }} \\
\hline & \multicolumn{2}{|c|}{ High Tide } & \multicolumn{2}{|c|}{ Low Tide } & & \\
\hline & $R^{2}$ & $p$ & $\mathbf{R}^{2}$ & $p$ & $\mathrm{R}^{2}$ & $p$ \\
\hline Salinity $\times$ Chlorophyll-a & 0.02 & 0.23 & 0.1 & $<0.01$ & 0.07 & $<0.01$ \\
\hline Salinity $\times$ Turbidity & 0.05 & 0.03 & 0.08 & $<0.01$ & 0.12 & $<0.01$ \\
\hline Salinity $\mathrm{X}$ acoom & 0.26 & $<0.01$ & 0.32 & $<0.01$ & 0.06 & $<0.01$ \\
\hline Salinity $\mathrm{X}$ Susp. Material & 0.16 & $<0.01$ & 0.11 & $<0.01$ & 0.24 & $<0.01$ \\
\hline Precipitation $\times$ Chlorophyll-a & 0.02 & 0.2 & 0.04 & 0.1 & 0.03 & 0.04 \\
\hline Precipitation X Salinity & 0.01 & 0.38 & 0.37 & $<0.01$ & 0.03 & 0.04 \\
\hline Precipitation $x$ Turbidity & 0.05 & 0.07 & 0.01 & 0.32 & 0.03 & 0.04 \\
\hline Precipitation X accom & 0 & 0.55 & 0.01 & 0.32 & 0 & 0.63 \\
\hline Precipitation $\mathrm{X}$ delta Salinity & - & . & . & . & 0.27 & $<0.01$ \\
\hline Water Disch. X Chlorophyll-a & 0 & 0.75 & 0.03 & 0.1 & 0 & 0.32 \\
\hline Water Disch. $\mathrm{x}$ Salinity & 0.06 & 0.03 & 0 & 0.4 & 0.02 & 0.05 \\
\hline Water Disch. $\times$ Turbidity & 0.03 & 0.14 & 0 & 0.67 & 0 & 0.28 \\
\hline Water Disch. X acoom & 0 & 0.42 & 0 & 0.34 & 0 & 0.88 \\
\hline Water Disch. X Susp. Material & 0 & 0.81 & 0 & 0.43 & 0 & 0.86 \\
\hline Water Disch. $\mathrm{X}$ delta Salinity & - & & - & - & 0.01 & 0.32 \\
\hline
\end{tabular}


As expected, values of $\mathrm{a}_{\mathrm{CDOM}}$ (Fig. 2D) were higher during ebb tides ( $<<0.01$, Fig. 3 ) when the influence of estuarine waters is more evident and salinity is lower (Table 1) consistent with the origin of CDOM from continental sources (BRICAUD et al., 1981). However, the lack of significant correlation found between $\mathrm{a}_{\mathrm{CDOM}}$ and both precipitation rates and water discharge (Table 1) suggests that a number of processes, other than estuarine discharges, occur in the São Vicente estuary and act as sources and sinks of CDOM. Among such possible processes, the local production of CDOM by phytoplankton (CARDER et al., 1989) may be considered, as is suggested by the small but significant correlation between $\mathrm{a}_{\mathrm{CDOM}}$ and [Chl] $\left(\mathrm{R}^{2}=0.03, \mathrm{p}=0.03\right)$. Note that, despite the significant differences found in salinity between high and low tides $(\mathrm{p}<0.01)$, we have observed higher salinity during the low tide on some specific days (Fig. 2C), perhaps a result of wind stress piling saltier water into the São Vicente embayment during low tide or of the entrance of freshwater patches, formed during previous continental runoffs, from Santos bay into the São Vicente embayment. However, there are as yet no studies of such features of the Santos estuarine system and we can only count on data from the modeling of the tidal current speed and water column height for the region (HARARI; CAMARGO, 1998).

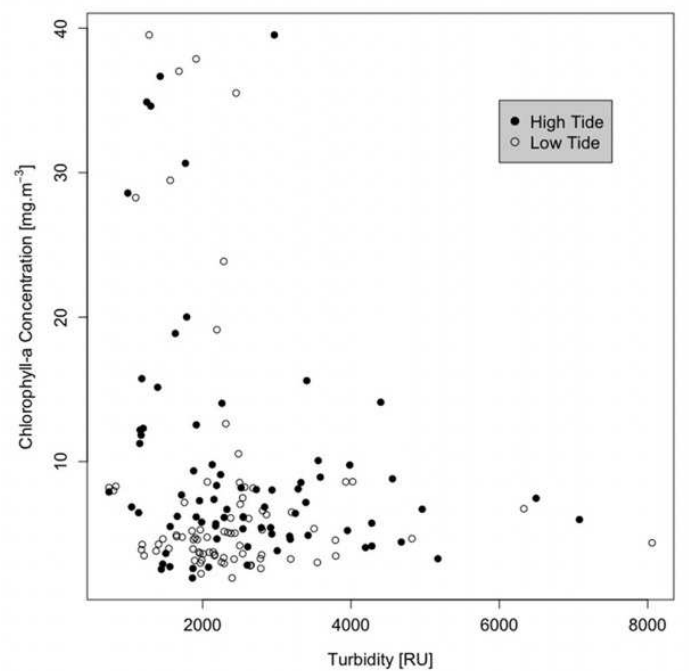

Fig. 3. Correlation of total water turbidity [RU] and Chlorophyll-a concentration $\left[\mathrm{mg} \cdot \mathrm{m}^{-3}\right.$ ] divided between tidal periods (High and Low Tide).

Thus, to assess the influence of local rain on [Chl] and turbidity, the time series was arbitrarily divided into two intervals according to precipitation rates; from February to June ("rainy period" with an average precipitation rate of $\left.12.58 \mathrm{~mm} \cdot \mathrm{day}^{-1}\right)$ and from June to September ("dry period" with $4.20 \mathrm{~mm}^{- \text {day }^{-1}}{ }^{-1}$. Note that the site 1 time series excludes the summer months when the highest precipitation rates are expected. Therefore, these results illustrate the role of precipitation during the remainder of the year. Significant differences are found in water turbidity only for tidal phases (Fig. 4B), while the magnitude of CDOM $\left(\mathrm{a}_{\mathrm{CDOM}}\right)$ showed a difference from the precipitation regime (Fig. 4C) and also the tidal phase (Fig. 4D). Salinity and suspended material also show significant differences between tidal phases and precipitation regimes ( $\mathrm{p}<0.01$; not shown). Our results suggest that, over scales of weeks to months, [Chl] in São Vicente embayment will correlate to two major forcing factors: tidal amplitude and precipitation rates.

\section{Site 2 - Short-term Observations}

As early works on the Santos estuarine complex highlighted the occurrence of phytoplankton blooms during the summer, a second time series study was conducted using a higher frequency of observations, for samples collected in the São Vicente estuarine channel during the slack high tide (site 2 in Fig. 1). The series showed successive bloom events, with [chl] reaching values over $85 \mathrm{mg} . \mathrm{m}^{-3}$ (e.g., third event at end of February in Fig. 5A). In general, during the summer phytoplankton biomass tended to increase between the last days of the neap tides and the early stages of the spring tides; however, no statistical differences between tidal regimes were found ( $p>0.05)$. In view of the results of the site 1 time series, it was also expected that [chl] variations in the São Vicente estuary would be guided (determined?) by fluctuations in water turbidity (MOSER et al., 2012; CLOERN, 1987), but there was no correlation between these variables either. However, values of water turbidity during the summer were on average 1458.05 [RU], little more than half of those observed at site 1 (2316.11 [RU]), suggesting that during the summer the water turbidity might not be the primary limiting factor for phytoplankton bloom development. Significant increases in [chl] were observed, however, during injections of ammonium into São Vicente channel $\left(\mathrm{R}^{2}=0.11, \mathrm{p}=0.04\right)$. Some phytoplankton genera, such as Skeletonema, can store ammonium during low light conditions, allowing bloom formation due to higher growth rates when conditions improve, outcompeting other phytoplankton genera (MARTINEZ, 1991). Skeletonema sp. species are abundant in Santos Bay during summer months (MOSER et al., 2012). Indeed, phytoplankton quantification under the inverted microscope revealed the predominance of Skeletonema sp., and possibly Skeletonema cf. costatum in most of the summer blooms (see "Phytoplankton Abundance" 
section below). Also, [chl] was negatively correlated positive response to water temperature $\left(R^{2}=0.53\right.$, $\mathrm{p}<0.01$ ), also indicating favorable growth rate conditions, which are generally observed in nutrient rich estuaries (CLOERN et al., 2005). In deep estuaries, summer stratification events can also benefit phytoplankton growth. Although deep samples were not collected during this series, it is reasonable to assume that during days of weak tidal currents, a vertical gradient of temperature may exist in the São Vicente estuary in the summer.
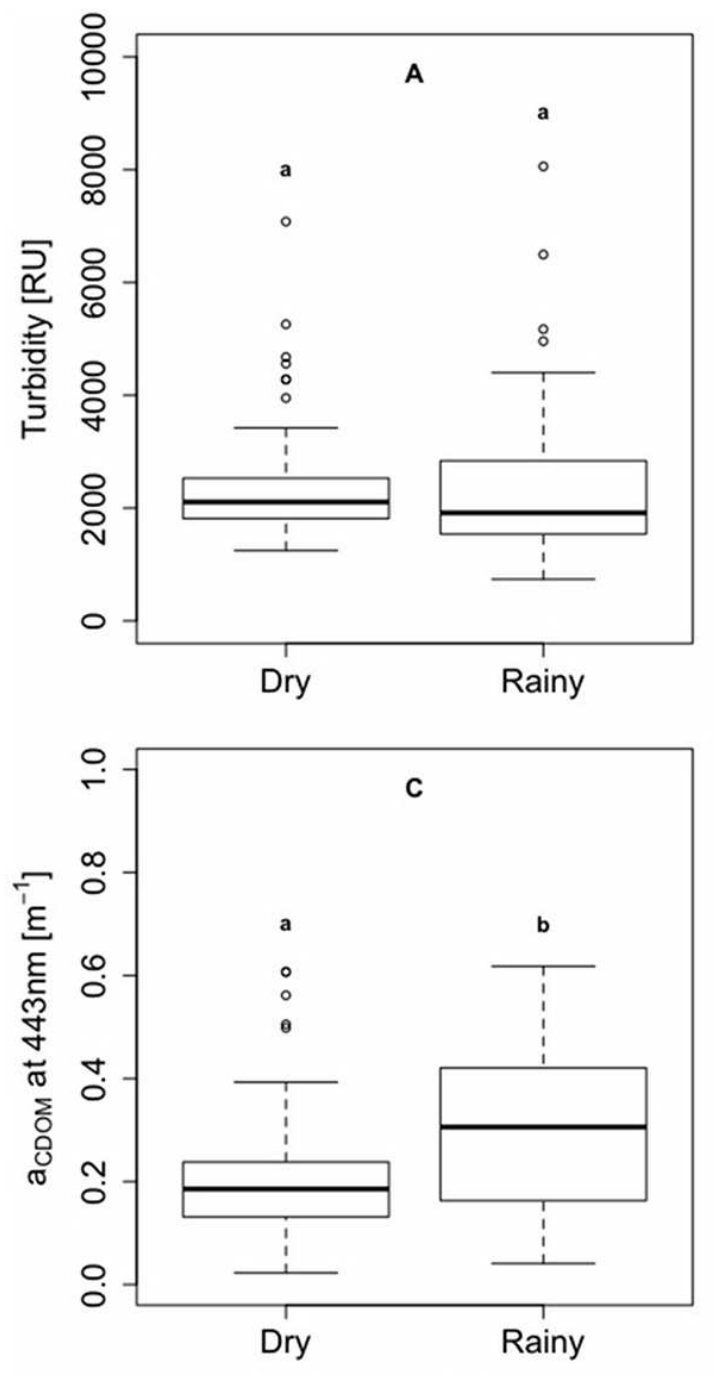

Precipitation Regime to salinity $\left(\mathrm{R}^{2}=0.17, \mathrm{p}=0.01\right)$ but had a more evident

Total water turbidity during the summer series (Fig. 5B) varied independently of any major forcing factor studied in this research (Table 2) and did not show any difference between the tidal regimes. Differently from site 1 , where local rain and tidal cycles, along with wave action (TOMIDA et al., unpublished data), directly affected suspended material in the water column, at site 2 the influence of these major forcing and freshwater flows was not evident, probably due to its greater depth $(10 \mathrm{~m})$ which made the resuspension of bottom sediments more difficult.
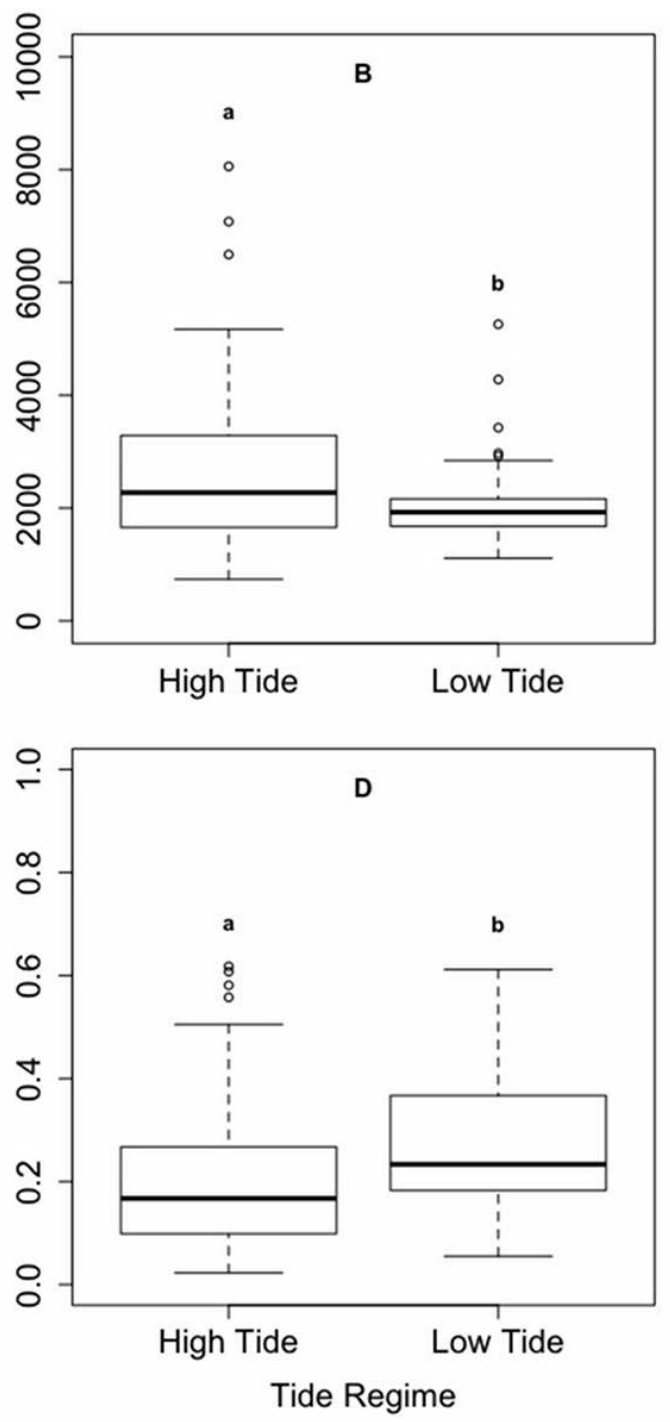

Fig. 4. Boxplot for water turbidity (A and B) and $\mathrm{a}_{\mathrm{CDom}}(\mathrm{C}$ and $\mathrm{D})$ among Precipitation regime (Rainy/Dry) and Tide Phase (High/Low). Bold line represents median of the data, box represents $75 \%$ distribution of data and the whiskers the confidence interval of $95 \%$, points are outliers. The letters ("a" and "b") above each box represent statistical difference of data (ANOVA test). 


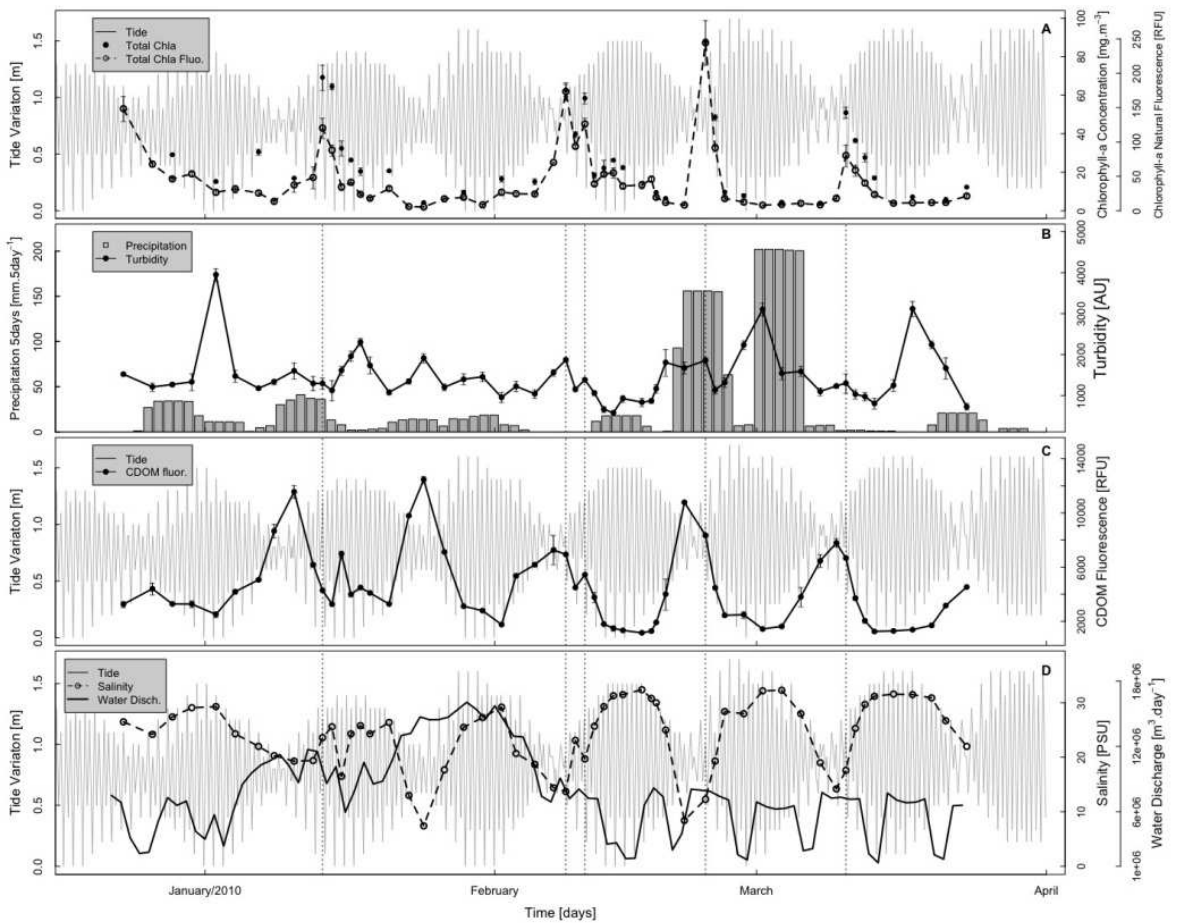

Fig. 5. Time series from site 2 during the summer of 2010 (December/2009 until March/2010). Points represent the average of six sub-replicas and vertical bars are the standard deviation. A) Tidal variation [m], Chlorophyll-a concentration [mg. $\left.\mathrm{m}^{-3}\right]$ and Natural Fluorescence of Chlorophyll-a [RFU]; B) Precipitation rate cumulative of 5 subsequent days $\left[\mathrm{mm}^{\left.-d a y^{-1}\right]}\right.$ and total water turbidity; C) Tidal variation [m] and CDOM fluorescence [RFU]; D) Tidal variation $[\mathrm{m}]$, daily water discharge from Henry Borden Hydroelectric Dam $\left[\mathrm{m}^{3} \cdot\right.$ day $\left.^{-1}\right]$ and salinity [PSU]. Vertical dotted lines represents the events of phytoplankton bloom formation.

Many environmental variables in estuaries will covary with freshwater inflows into the system, contributing effectively to biological responses (BRANDT et al., 1986). However, contrary to what was expected, local precipitation rates were low throughout the series $\left(7.81 \mathrm{~mm} \cdot \mathrm{day}^{-1}\right)$ and did not significantly influence any of the variables studied(Table 2). Water discharges from the Henry Borden Hydroelectric Dam, however, attained values six times greater than those observed during the series at site 1 (averages: site $1=1,182,174 \mathrm{~m}^{3}$.day ${ }^{-1}$, site $2=7,721,687 \mathrm{~m}^{3} \cdot \mathrm{day}^{-1}, \mathrm{p}<0.01$ ) directly affecting the water quality of the São Vicente channel (Table 2).

To assess the influence of the Henry Borden (hereafter called HB) Dam's water discharges into São Vicente estuary, we arbitrarily divided series 2 database into two subsets according to values of water discharge so that "High Discharge" represents values greater than 9 million $\mathrm{m}^{3}$.day ${ }^{-1}$ while "Regular Discharge" represents values lower than 9 million $\mathrm{m}^{3} \cdot$ day $^{-1}$

CDOM fluorescence, as a proxy for CDOM concentration, at site 2 develops a common pattern of oscillation with the tidal regime, peaking during neap tides (Fig. 5C). CDOM fluorescence is strongly correlated to salinity during the summer series $\left(\mathrm{R}^{2}=0.87, \mathrm{p}<0.01\right.$, Table 2$)$, consistently with an important continental source (BRICAUD et al., 1981). CDOM fluorescence was statistically different between tidal regimes (classified as spring, neap and intermediary; see methods) with the highest values observed during neap tides (Fig. 6A), especially during freshwater inflows. Nonetheless, periods of most intensive water discharge from the Henry Borden Dam into the estuary significantly increased CDOM fluorescence values (Fig. 6B).

Salinity showed a remarkable oscillation pattern in accordance with the tides (Fig. 5D), with lower values during neap tides (Fig. 6C) and intense water discharge (Fig. 6D). Freshwater flow into the São Vicente channel also intensified nutrient load, with visible increases in nitrate+nitrite (hereafter $\mathrm{NN}$ ) and phosphate concentrations (Table 2). The strong negative correlation between nutrients and salinity (Table 2) and their differences according to tidal regime with higher concentrations during neap tide $(\mathrm{p}<0.01$, not shown) indicate the terrestrial source of these macronutrients. Increased nutrient loads can 
stimulate phytoplankton production and lead to accumulation of biomass and bloom formation in estuaries (e.g. DE JONGE et al., 1994). However, [chl] does not correlate to increases in nutrient concentration on a day-to-day basis, there being a lag of 1 to 2 days before [chl] responds to increases in nutrient concentration (Fig. 7).

Table 2. Summary of correlation $\left(\mathrm{R}^{2}\right)$ expected from site 2 . For explanatory variables we used salinity, Henry Borden water discharge, local precipitation and macronutrients concentration to explain variations in water parameters. pvalues in bold represent statistical significance.

\begin{tabular}{lcc} 
& \multicolumn{2}{c}{ Linear Correlation } \\
\cline { 2 - 3 } & $\mathbf{R}^{\mathbf{2}}$ & $\mathbf{P}$ \\
\hline Salinity X Chlorophyll-a & 0.17 & $\mathbf{0 . 0 1}$ \\
Salinity X Turbidity & 0 & 0.9 \\
Salinity X CDOM Fluor. & 0.87 & $<\mathbf{0 . 0 1}$ \\
Salinity X Ammonium & 0.45 & $<\mathbf{0 . 0 1}$ \\
Salinity X NN & 0.39 & $<\mathbf{0 . 0 1}$ \\
Salinity X Silicate & 0.3 & $<\mathbf{0 . 0 1}$ \\
Salinity X Phosphate & 0.33 & $<\mathbf{0 . 0 1}$ \\
Precipitation X Chlorophyll-a & 0 & 0.37 \\
Precipitation X Salinity & 0 & 0.21 \\
Precipitation X Turbidity & 0 & 0.41 \\
Precipitation X CDOM Fluor. & 0 & 0.2 \\
Precipitation X Ammonium & 0 & 0.27 \\
Precipitation X NN & 0 & 0.12 \\
Precipitation X Silicate & 0 & 0.16 \\
Precipitation X Phosphate & 0 & 0.14 \\
Water Disch. X Chlorophyll-a & 0 & 0.4 \\
Water Disch. X Salinity & 0.11 & $\mathbf{0 . 0 1}$ \\
Water Disch. X Turbidity & 0 & 0.86 \\
Water Disch. X CDOM Fluor. & 0.12 & $<\mathbf{0 . 0 1}$ \\
Water Disch. X Ammonium & 0 & 0.1 \\
Water Disch. X NN & 0.21 & $<\mathbf{0 . 0 1}$ \\
Water Disch. X Silicate & 0.07 & 0.05 \\
Water Disch. X Phosphate & 0.14 & $<\mathbf{0 . 0 1}$ \\
Ammonium X Chlorophyll-a & 0.11 & $\mathbf{0 . 0 4}$ \\
NN X Chlorophyll-a & 0.08 & 0.09 \\
Silicate X Chlorophyll-a & 0 & 0.18 \\
Phosphate X Chlorophyll-a & 0 & 0.4 \\
Temperature X Chlorophyll-a & 0.53 & $<\mathbf{0 . 0 1}$ \\
\hline & & \\
& 0.45 \\
\hline
\end{tabular}

Despite the absence of statistical relationships between [chl] and water discharge, HB freshwater discharges clearly altered the frequencies of phytoplankton summer blooms in the São Vicente channel. When Figures 5A and 5D are compared, it is possible to identify an approximate frequency of about 15 days, confirmed by wavelet analysis (Fig. 8, red area), usually at the end of neap tides. Nonetheless, this pattern is disrupted during intensive HB water discharges, and the time interval between blooms is closer to a month. Variations in freshwater inputs in estuaries have been reported to promote variations in physical conditions and depending on their intensity, they might flush phytoplankton out of small embayments (DE MADARIAGA et. al., 1992, RENDELL et al., 1997). It is noteworthy that most anthropogenic alterations in estuarine systems lead to a decrease in freshwater inflows due to agricultural uses (e.g. NICHOLS et al., 1986) or modifications of estuarine channels (dredging; EWA-OBOHO et al., 2008) so that the estuaries become saltier with the inevitable ecological implications (e.g. WHITFIELD; BRUTON, 1989). In the São Vicente estuary, episodic increments in water discharge due to $\mathrm{HB}$ scape pipes clearly affected the frequency of natural summer blooms, as has been observed in other estuaries (NIXON, 2003; LEPAGE; INGRAM, 1986). These events may certainly modify the adjacent continental shelf waters (see CARVALHO et al., submitted).

\section{Site 2 - Phytoplankton Abundance}

Overall, diatoms were the predominant group among microphytoplankton (Fig. 9A) while Cyanobacteria represented the least abundant group. Distinct phytoplankton communities appeared during bloom events. During the first bloom, the microphytoplankton community was initially composed of Protoperidinium sp, Cylindrotheca closterium and Skeletonema cf. costatum, which then changed into a community dominated by centric chain diatoms, mostly Skeletonema cf. costatum. During the second bloom, the community was initially dominated by chain-forming diatoms, especially Thalassiosira $\mathrm{cf}$. rotula that accounted for $80 \%$ of microphytoplankton abundance, and was progressively replaced by dinoflagellate (Protoperidinium sp and Scrippsiella $\mathrm{sp})$ and pennate diatom (Navicula $\mathrm{sp}$ ) dominance. Changes in community structure within a bloom event can result from variations in the nutrient ratios, favoring different species (TILMAN et al., 1982) and shifts in water column stability and transparency (LAURIA et al., 1999). While Increases in vertical mixing can favor the predominance of diatoms (JONES et al., 1984), sustaining water column stratification for long periods will favor motile species such as dinoflagellates and flagelattes (JONES; GOWEN, 1990).

During the second bloom, between changes in microphytoplankton composition, [chl] values drop but are quickly reestablished (Fig. 5A). As this disturbance is also observed in salinity (Fig. 5D), the changes in predominance of motile species such as Protoperidinium sp may reflect the presence of a vertical salinity gradient (JONES; GOWEN, 1990). However, dominant phytoplankton cell size (estimated by fractionated [chl] fluorescence) showed that smallsized organisms $(<20 \mu \mathrm{m})$ were relatively important during all the blooms, except during January's (Fig. 9B). The lower size limit of our microscopic enumerations is around $5 \mu \mathrm{m}$, so much of the community structure could not be observed even at genera level. 

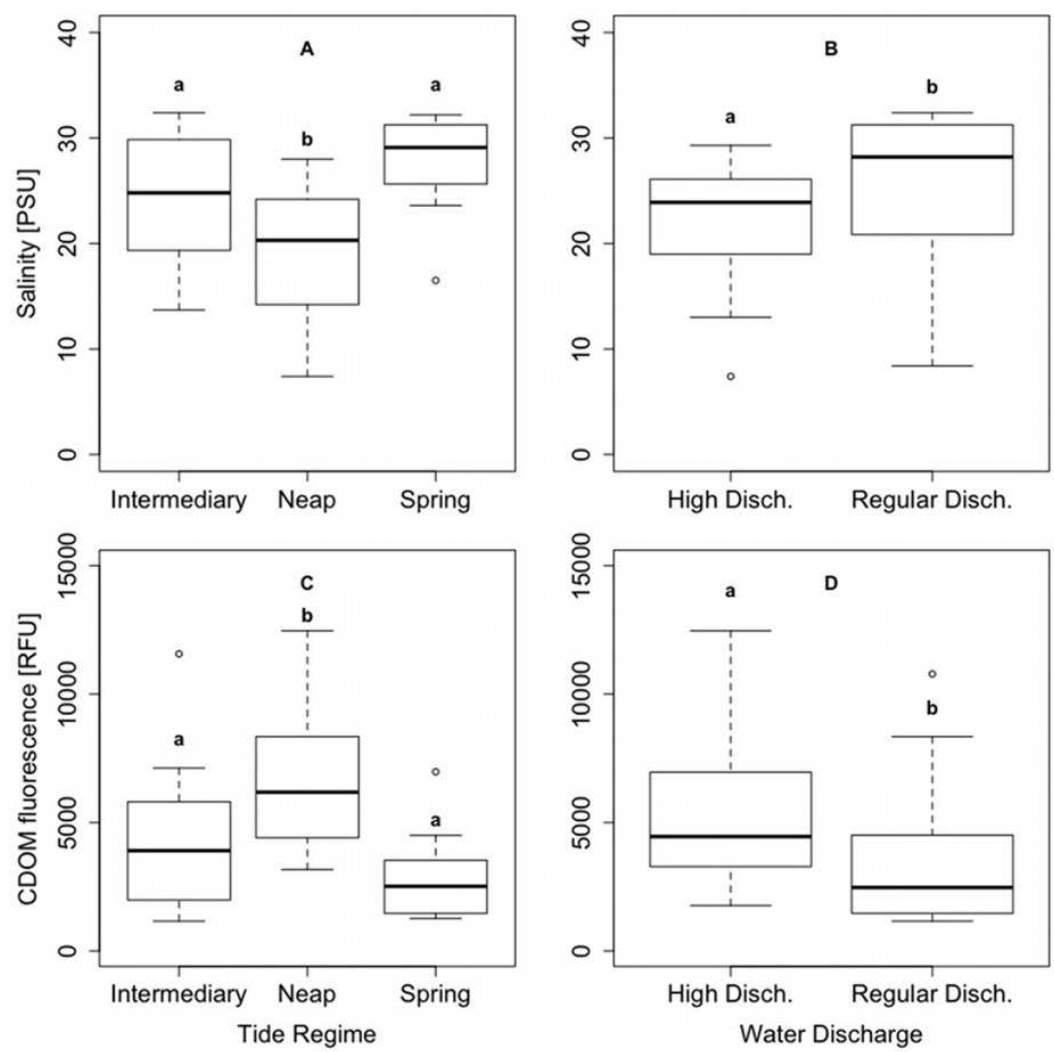

Fig. 6. Boxplot for Salinity [PSU] (A and B) and CDOM fluorescence [RFU] (C and D) among Tidal Regime (Intermediary/Neap/Spring) and Water Discharge regime from Henry Borden Dam (High Discharge/Regular Discharge). Bold line represents median of the data, box represents $75 \%$ distribution of data and the whiskers the confidence interval of $95 \%$, points are outliers. The letters ("a" and "b") above each box represent statistical difference of data (ANOVA and Tukey (posteriori) tests).

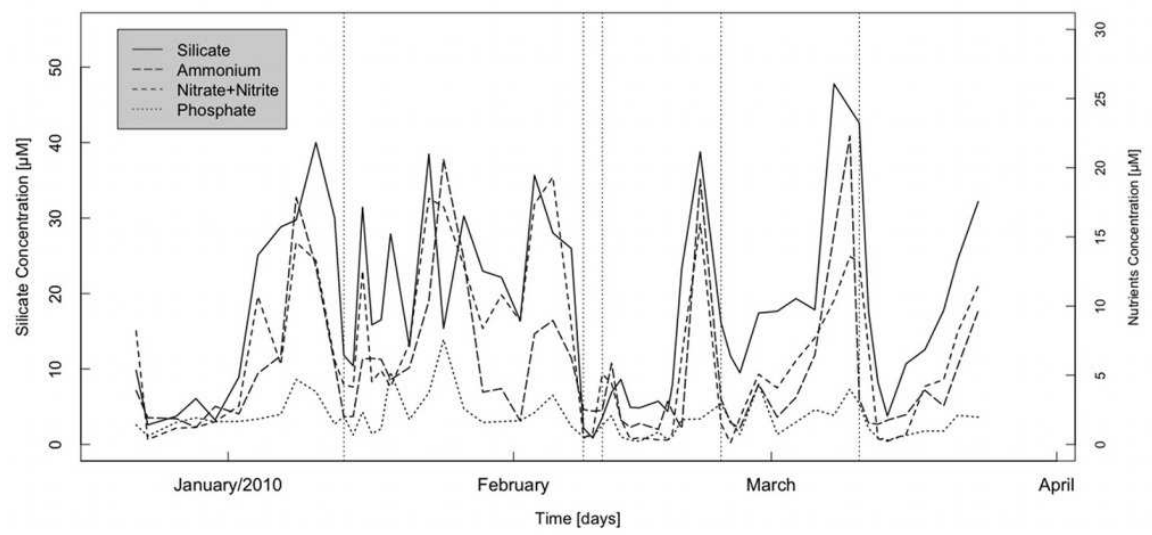

Fig. 7. Site 2 macronutrients concentration $[\mu \mathrm{M}]$ time series. Vertical dotted lines represent phytoplankton bloom formation. 
The third bloom was dominated by Cylindrotheca closterium that accounted for up to $90 \%$ of the total microphytoplankton, maintaining this proportion for the full duration of the bloom (Fig. 9A). During the last bloom event, the flagellate contribution is more evident (Fig. 9A), attaining up to $30 \%$ of all the cells counted - with Eutreptiella spp being the most abundant organism. During the bloom itself, relatively equal proportions of centric and pennate diatoms and flagellates were present, followed by a minor proportion of dinoflagellates. The increase in flagellate organisms in our samples indicates that, during the formation of this bloom, the effects of freshwater were more evident, since the genera Eutreptiella $\mathrm{sp}$ is usually composed of freshwater species (TOMAS, 1997).

Our results have thus confirmed the hypothesis of increasing [chl] during neap summer tides, but there is no evidence of water turbidity controlling [chl] values. Species cell size and composition seem to be modulated by the salinity conditions created by the tidal regimes and HB's fresh water discharges which, when they are above 9 million $\mathrm{m}^{3}$.day ${ }^{-1}$, disrupt the tide-driven bloom frequencies.

\section{Conclusions}

Fluctuations in chlorophyll concentration in the São Vicente estuary seem to be linked to the tides and water turbidity. During fall and winter, chlorophyll-a concentration remained within a narrow range in response to the high turbidity of the water due to the sediments transported from Santos bay. In the summer, on a smaller observation scale, chlorophyll-a fluctuations were consistently observed with bloom formation at the end of neap tide periods when the stability of the water column was greater. These variations were naturally modulated by tidal cycles but strongly affected by freshwater discharge into the estuary, modifying phytoplankton bloom frequencies. Weekly to monthly scale observations are important to identify seasonal variations in phytoplankton biomass and the major oceanographic features regulating phytoplankton occurrence in an estuary. However, they lack the evidence of episodic features influencing the phytoplankton community such as appear in high frequency observations. We suggest an increase in short-term studies with high frequency observations in the Santos estuarine system in order to understand local phytoplankton community dynamics and develop adequate long-term monitoring strategies.
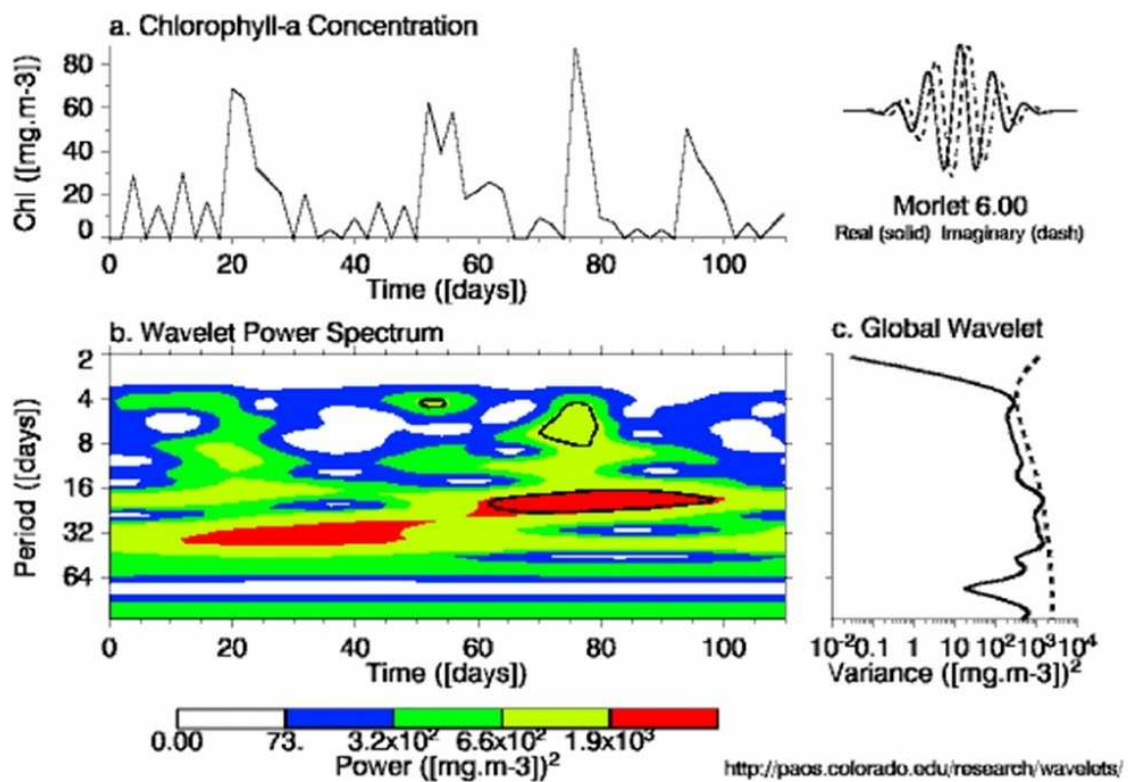

Fig. 8. Chlorophyll-a Wavelet Analysis. a) Chlorophyll-a concentration [mg. $\left.\mathrm{m}^{-3}\right]$. b) The wavelet power spectrum. The contour levels are chosen so that $75 \%, 50 \%, 25 \%$, and $5 \%$ of the wavelet power is above each level, respectively. Black contour is the $5 \%$ significance level, using a red-noise (autoregressive lag1) background spectrum. c) The global wavelet power spectrum (black line). The dashed line is the significance for the global wavelet spectrum, assuming the same significance level and background spectrum as in (b). Analysis conducted under online script (http://atoc.colorado.edu/research/wavelets/) freely provided by the Department of Atmospheric and Oceanic Sciences, University of Colorado Boulder. Reference: Torrence and Compo (1998). 


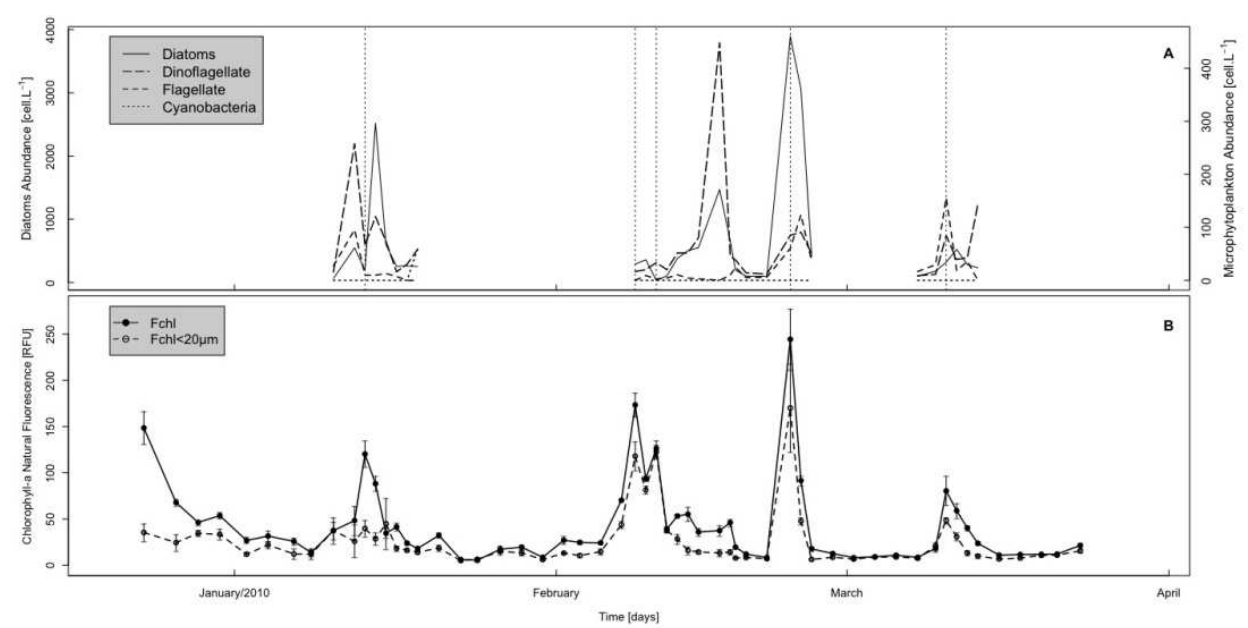

Fig. 9. Site 2 microphytoplankton abundance [cell.L ${ }^{-1}$ ] (A) and Chlorophyll-a Natural Fluorescence [RFU] (B). Vertical dotted lines represent phytoplankton bloom formation. We divided Diatoms from the rest of the phytoplankton major groups due to the huge difference of values range.

\section{ACKNOWLEDGEMENTS}

We would like to thank the Atlantis Association for Research Development for AF Bucci's scholarship. The staff of the Henry Borden Hydroelectric Dam (EMAE - "Empresa Metropolitana de Águas e Energia S.A.") for kindly making available daily water discharge data. We are in debt to Renato Tonini, Thiago Valente, Kleber Baraldo and Elena Galvanese for the sampling efforts. We would also like to thank the anonymous revisor for his suggestions on this article.

\section{REFERENCES}

ALPINE, A. E.; CLOERN, J. E. Trophic interactions and direct physical effects control phytoplankton biomass and production in an estuary. Limnol. Oceanogr., v.37, n.5, p.946-955, 1992.

ANDERSON, D. M.; CHISHOLM, S.W.; WATRAS, C. J. Importance of life cycle events in the population dynamics of Gonyaulax tamarensis. Mar. Biol., v.76, p.179-189, 1983.

BABIN, M.; STRAMSKI, D.; FERRARI, G. M.; CLAUSTRE, H.; BRICAUD, A.; OBOLENSKY, G.; HOEPFFNER, N. Variations in the light absorption coefficients of phytoplankton, non-algal particles, and dissolved organic matter in coastal waters around Europe. J. Geophys. Res., v.108, n.C7, p. 4.1-4.20, 2003. 10.1029/2001JC000882

BRANDT, A.; SARABUN, C. C.; SELIGER, H. H.; TYLER, M. A. The effects of a broad spectrum of physical activity on the biological processes in the Chesapeake Bay. In: NIHOUL, J. C. J. Marine interfaces ecohydrodynamics. Amsterdan: Elsevier, 1986, p.361-384.

BRICAUD, A.; MOREL, A.; PRIEUR, L. Absorption by dissolved organic matter of the sea (yellow substance) in the UV and visible domains. Limnol. Oceanogr., v.26, p.43-53, 1981.
CARDER, K. L.; STEWARD, R. G.; HARVEY; G. R.; ORTNER, P. B. Marine humic and fulvic acids: their effects on remote sensing of ocean chlorophyll. Limnol. Oceanogr., v.34, p.68-81, 1989.

CARPENTER, S. R.; CARACO, N. F.; CORRELL, D. L.; HOWARTH, R. W.; SHARPLEY, A. N.; SMITH, V. H. Nonpoint pollution of surface waters with phosphorus and nitrogen. Ecol. Appl.., v.8, p.559-568, 1998.

CARVALHO, M.; CIOTTI, A. M.; GIANESELLA, S. M. F.; SALDANHA-CORRÊA, F. M. P.; PERINOTTO, R. R. C. Bio-optical properties of the inner continental shelf off Santos estuarine system, Southeast of Brazil, and implications for ocean color algorithms performance. Braz. J. Oceanogr., submitted.

CBH-BS (COMITÊ DE BACIA HIDROGRÁFICA DA BAIXADA SANTISTA DEPARTAMENTO DE ÁGUAS E ENERGIA ELÉTRICA). Relatório de Situação dos Recursos Hídricos da Bacia Hidrográfica da Baixada Santista, 2007. ( Relatório I. v.2).

CHEN, M. S.; WARTEL, S.; VAN ECK, B.; VAN MALDEGEM, D. Suspended matter in the Scheldt estuary. Hydrobiologia, v.540, p.79-104, 2005.

CLOERN, J. E. Turbidity as a control on phytoplankton biomass and productivity in estuaries. Cont. Shelf. Res., v.7, p.14, 1987.

CLOERN, J. E. Tidal stirring and phytoplankton bloom dynamics in an estuary. J. Mar. Res., v.49, p.203-221, 1991.

CLOERN, J. E.; JASSBY, A. D. Patterns and scales of phytoplankton variability in estuarine-coastal ecosystems. Estuaries Coasts, v.33, p.230-241. 2010. DOI 10.1007/s12237-009-9195-3

CLOERN, J. E.; SCHRAGA, T. S.; LOPEZ, C. B.; KNOWLES, N.; LABIOSA, R. G.; DUGDALE, R. Climate anomalies generated an exceptional dinoflagellate bloom in San Francisco Bay. Geophys. Res. Lett.,v.23: LI4608, 2005.

CONLEY, D. J. Biogeochemical nutrient cycles and nutrient management strategies. Hydrobiologia, v.410, p.87-96, 2000. 
DE JONGE, V. N.; BOYNTON, W.; D'ELIA, C. F. ELMGREN, R.; WELSH,B. L. Responses to developments in eutrophication in four different North Atlantic estuarine systems. In: DYER, K. R.; ORTH, R. $\mathrm{J}$. Changes in fluxes in estuaries. Fredensborg, Denmark: Olsen \& Olsen, 1994. p.179-196.

DE JONGE, V. N.; ELLIOTT, M.; ORIVE, E. Causes, historical developments, effects and future challenges of a common environmental problem: Eutrophication. Hydrobiologia, v.475/476, p.1-19, 2002

DE MADARIAGA, I.; GONZALEZ-AZPIRI, L.; VILLATE, F.; ORIVE, E. Plankton responses to hydrological changes induced by freshets in a shallow mesotidal estuary. Estuar. Coast. Shelf Sci., v.35, p.425-434, 1992.

DEMERS, S.; LEGENDRE, L.; THERRIAULT, J. C. Phytoplankton responses to vertical tidal mixing. Lect. Notes Coast. Estuar. Stud., v.17, p.1-39, 1986.

DYNESIUS, M.; C. NILSSON. Fragmentation and flow regulation of river systems in the northern third of the world. Science, v. 266, p.753-762, 1994.

EWA-OBOHO, I; OLADIMEJI, O.; ASUQUO, F. E. Effect of dredging on benthic-pelagic production in the mouth of Cross River Estuary (off the Gulf of Guinea), S. E. Nigeria. Indian J. Mar. Sci., v.37, n.3, p.291-297, 2008.

FOSTER, P.; MORRIS, A. W. Seasonal distribution of ultraviolet absorption in the surface waters of Liverpool Bay. Estuar. Coast. Mar. Sci., v.2, n.3, p.283-290, 1974.

GRASSHOFF, K.; EHRHARDT, M.; KREMLING K. Methods of seawater analysis. Revised and extended 2.ed. Wienhien: Verlag Chemie, 1983. $419 \mathrm{p}$.

HAAS, L. W.; HASTINGS, S. J.; WEBB, K. L. Phytoplankton response to a stratification-mixing cycle in the York River estuary during late summer. In: NEILSON, B. J.; CRONIN, L. E. Estuaries and nutrients. Clifton: Humana Press, 1981. p.619-636.

HARARI, J.; CAMARGO, R. Modelagem numérica da região costeira de Santos (SP): circulação de maré. Rev. Bras. Oceanogr., v. 46, n.2, p.135-156, 1998.

HARARI, J.; GORDON, M. Simulações numéricas da dispersão de substâncias no Porto e Baía de Santos, sob a ação de marés e ventos. Rev. Bras. Recurs. Hídr., v.6, n.2, p.115-131, 2001.

HARARI, J.; CAMARGO, R. and CACCIARI, P. L. eResultados da modelagem numérica hidrodinâmica em simulações tridimensionais das correntes de maré da Baixada Santista. Rev. Bras .Recurs. Hídr., v.5, n.2, p.71-87, 2000.

HUMBORG, C.; CONLEY, D.J.; RAHM, L.; WULFF, F.; COCIASU, A.; ITTEKKOT, V. Silicon retention in river basins: far reaching effects on biogeochemistry and aquatic food webs in coastal marine environments. Ambio, v.29, p.45-50, 2000.

JONES, K. J.; GOWEN, R. J. Influence of stratification and irradiance regime on summer phytoplankton composition in coastal and shelf seas of British Isles. Estuar.Coast. Shelf Sci. v.30, p.557-567, 1990. ine

JONES, K. J.; GOWEN, R. J; TETT, P. Water column structure and summer phytoplankton distribution in the sound of Jura, Scotland. Journal of Experimental Marine Biology and Ecology, v.78, p.269-289, 1984.
KOROLEFF, F. Direct determination of ammonia in natural waters as indophenol blue. ICES, CM 1969/C: 9. Hydr. Comm., 1969.

LAURIA, M. L.; PURDIE, D. A.; SHARPLES, J. Contrasting phytoplankton distributions controlled by tidal turbulence in an estuary. J. Mar. Syst., v.21, p.189197, 1999.

LEPAGE, S.; INGRAM, R. G. Salinity intrusion in the Eastmain River estuary following a major reduction in freshwater input. J. Geophys. Res., v.91, n.C1, p.909915, 1986.

MARTINEZ, R. Transient nitrate uptake and assimilation in Skeletonema costatum cultures subject to nitrate starvation under low irradiance. J. Plankton Res., v.13, n.3, p.499-512, 1991.

MOSER, G. A. O.; GIANESELLA, S. M. F.; ALBA, J. J. B.; BERGAMO, A. L.; SALDANHA-CORREA, F. M. P.; MIRANDA, L. B.; HARARI, J. Instantaneous transport of salt, nutrients, suspended matter and chlorophyll-a in the tropical estuarine system of Santos. Braz. J. Oceanogr., v.53, n.3/4, p.115-127, 2005.

MOSER, G. A. O.; CIOTTI, A. M.; GIANNINI, M. F. C.; TONINI, R. T.; HARARI, J. Changes in phytoplankton composition in response to tides, wind-induced mixing conditions, and freshwater outflows in an urbanized estuarine complex. Braz. J. Biol., v.72, p.97-111, 2012.

NICHOLS, F. H.; CLOERN, J. E.; LUOMA, S. N.; PETERSON, D. H. The modification of an estuary. Science, v.231, p.567-573, 1986.

NIXON, S. W. Coastal marine eutrophication: a definition. Social causes, and future concerns. Ophelia, v.41, p.199219, 1995.

NIXON,S. W. Replacing the Nile: are anthropogenic nutrients providing the fertility once brought to the Mediterranean by a great river? Ambio, v.32, p.30-39, 2003.

PAERL, H. W.; ROSSIGNOL, K. L.; HALL, N. S.; PEIERLS, B. L.; WETZ,M. S. Phytoplankton community indicators of short and long- term ecological change in the anthropogenically and climatically impacted Neuse River Estuary, North Carolina, USA. Estuaries Coasts, 2009. DOI:10.1007/s12237-0099137-0.

PETERSEN, J. K.; HANSEN, J. W.; LAURSEN, M. B.; CLAUSEN, P.; CARSTENSEN, J.; CONLEY, D. J. Regime shift in a coastal marine ecosystem. Ecological Appl., v.18, p.497-510, 2008.

R DEVELOPMENT CORE TEAM. R: A language and environment for statistical computing. Vienna: R Foundation for Statistical Computing, 2011. -90005107-0, URL http://www.R-project.org/.

RENDELL, A. R.; HORROBIN, T. M.; JICKELLS, T. D.; EDMUNDS, H. M.; BROWN, J.; MALCOLM, S. J. Nutrient cycling in the Great Ouse Estuary and its impact on nutrient fluxes to the Wash, England. Estuar._Coast. Shelf Sci., v.45, p.653-668, 1997.

SCHMIEGELOW, J. M. M.; GIANESELLA, S. M. F.; SIMONETTI, C.; SALDANHA-CORREA, F. M. P.; FEOLI, E., SANTOS, J. A. P.; SANTOS, M. P.; RIBEIRO, R. B.; SAMPAIO, A. F. P. Primary producers in Santos estuarine system. In: NEVES, R.; BARETTA, J.; MATEUS, M. Perspectives on integrated coastal zone management in South America. Lisboa: IST Press, 2008. p.161-174. 
SHIKATA, T.; NAGASOE, S.; MATSUBARA, T: YOSHIKAWA, S.; YAMASAKI, Y.; SHIMASAKI, Y.; OSHIMA, Y.; JENKINSON, I. R.; HONJO, T. Factors influencing the initiation of blooms of the raphidophyte Heterosigma akashiwo and the diatom Skeletonema costatum in a port in Japan. Limnol. Oceanogr., v.53, p.2503-2518, 2008.

SHOAF, W. T.; LIUM, B.W. Improved extraction of chlorophyll $\mathrm{a}$ and $\mathrm{b}$ from algae using dimethylsulfoxide. Liminol. Oceanogr., v.21, p.926-928, 1976.

STRICKLAND, J. D. H.; PARSONS, T. R. A pratical handbook of seawater analysis. Ottawa: Fisheries Research Board of Canada, 1972.310 p.

TILMAN, D.; KILHAM, S. S.; KILHAM, P. Phytoplankton community ecology: the role of limiting nutrients. Annu Rev. Ecol.Syst., v.13, p.349-372, 1982.

TOMAS, C. R. Identifying marine phytoplankton. San Diego: Academic Press, 1997. 858 p.

UTERMÖHL, H. Neue wege in der quantitativen. Erfassung des planktons. Verhandlungen Internationalen Vereinigung Theoretische Angewandte Limnologie, v.5, n.2, p.567-596, 1931.
VILLAC, M. C; CABRAL-NORONHA, V. A. P.; PINTO, T. $\mathrm{O}$. The phytoplankton biodiversity of the coast of the state of São Paulo, Brazil. Biota Neotrop.ica, v.8, n.3, p.151-173, 2008 .

WELSCHMEYER, N. A. Analysis of chlorophyll a in the presence of chlorophyll $\mathrm{b}$ and pheopigments. Limnol. Oceanogr., v.39, n.8, p.1-7, 1994.

WHITFIELD, A. K.; BRUTON, M. N. Some biological implications of reduced fresh water inflow into eastern Cape estuaries: a preliminary assessment. S Afr. J. Sci., v.85, p.691-694, 1989.

(Manuscript received 09 May 2012; revised 20 November 2012; accepted 21 November 2012) 